然

DE GRUYter DOI: $10.2478 / \mathrm{v} 10129-011-0076-0$

K. Vishwanath ${ }^{1 *}$, H.M. Pallavi ${ }^{2}$, N. Nethra ${ }^{1}$, S. Rajendra Prasad ${ }^{3}$

${ }^{1}$ Department of Seed Science and Technology, University of Agricultural Sciences, GKVK, Bangalore, India; ${ }^{2}$ Department of Seed Technology, University of Horticultural, Sciences Bagalkot, India; ${ }^{3}$ Project Directorate (Seeds), Directorate of Seed Research, Mau, India; *Corresponding Author: vishwakoti@gmail.com

\title{
CHEMICAL TESTS FOR IDENTIFICATION AND CHARACTERIZATION OF TOMATO CULTIVARS
}

\begin{abstract}
Various chemical tests are being used to reveal chemical differences among the seeds or seedlings of different cultivars. Study to characterize and identify 24 tomato cultivars based on chemical test chemicals viz., Standard phenol test, Modified phenol test, $\mathrm{NaOH}$ test, $\mathrm{KOH}$ test and Seedling growth response to added chemicals reveled that, most of the cultivars studied were distinct from other cultivars. No single chemical test could distinguish all the varieties. However, distinguishable chemical characteristics were used to develop the keys for identification of each and every cultivar and all the cultivars were distinguished based on these identification keys.
\end{abstract}

Key words: chemical tests, tomato, varietal characterization

\section{INTRODUCTION}

Tomato (Lycopersicon esculentun L.) is the world's largest vegetable crop and known as productive and protective food because of its special nutritive value and wide spread production. Although it was introduced to India in the $18^{\text {th }}$ century, its commercial cultivation began towards the end of last century. It is economically important for its edible fruits and preserved products like ketch-up, sauce, chutney, soup, paste, puree etc. Tomato is a rich source of minerals, vitamins and organic acids, essential amino acids and dietary fibers. It is also rich source of vitamin

Communicated by Andrzej Aniol 
$\mathrm{A}$ and $\mathrm{C}$, it contains minerals like iron, phosphorus and pigments lycopene and beta -carotene.

At present, large number of varieties and hybrids with special regard to yield, fruit quality, resistant to biotic and abiotic stresses are under cultivation throughout the country. In recent years public institutions and private companies introduces one after the other hybrids/varieties for commercial cultivation. Therefore, the discrimination of tomato varieties, especially by examination of the seed is increasingly important in order to protect the breeders and farmers rights (Wang et al., 2000) and to ensure genetic purity or genuineness of variety which is most important characteristics of a quality seed.

The most common method of varietal identification is grow out test (Arus et al., 1982), which is based on the morphological markers, has many disadvantages such as interaction with environment, high cost and lengthy time required, low polymorphism in closely related varieties which were bred by using elite lines, to name but a few. Recent discoveries in the area of biochemistry and molecular biology have enabled seed scientist to utilize new techniques for cultivar identification to augment existing traditional methods. Proteins, isozymes and DNA markers are independent of environmental factors, these markers have been used to characterize (Tanksley et al.,, 1992; Lucchese et al., 1999, Vishwanath et al., 2010) However, these requires high investment cost and sophisticated lab facility and skilled personnel. Therefore it is necessary to find simple and cost effective techniques for characterization and identification of tomato cultivars.

Reaction of seeds or seedlings to different chemicals is based on seed composition; this property has been used by several researchers to characterize many crop cultivars (Papp et al., 1997, Vanangamudi et al., 1998, McDonald Jr., 1985, Punia et al., 2002, Patil et al., 2006; Nethra et al., 2007). There are several tests for varietal identification and the important tests are the soybean seed coat peroxidase test, oat seed fluorescence test, $\mathrm{KOH}-b l e a c h$ test for sorghum, $\mathrm{HCl}$ tests for oats, the phenol test for wheat, Poa pratensis and Lolium perenne, the $\mathrm{NaOH}$ test to distinguish red and white wheat and rice varieties, the ammonia fluorescence test to distinguish Festuca rubra and $F$. longifolia, $\mathrm{CuSO}_{4}$-ammonia test to distinguish Melilotus officinalis and M. alba, and the fluorescence test for Lolium perenne and L. multiflorum (ISTA, 1993; Mc Donald- Jr., 1985). However, among rapid chemical tests no single test was tried for tomato cultivar identification. Hence, different chemicals were used to reveal chemical reaction on seed constituents for characterization and identification of tomato cultivars.

\section{MATERIALS AND METHOD}

Seed samples of twenty four cultivars which are under cultivation in the state were collected from public and private organizations (Table 1) and subjected for different chemical tests . 
Cultivarsoftomatousedforvarietalcharacterization

\begin{tabular}{clllll}
\hline Sl No. & Cultivar & $\begin{array}{c}\text { Developed institute/ } \\
\text { company }\end{array}$ & Sl No. & Cultivar & $\begin{array}{c}\text { Developed institute/ } \\
\text { company }\end{array}$ \\
\hline 1. & Arka Alok & IIHR & 13. & Nandi & UASB \\
2. & Arka Vikas & IIHR & 14. & Sankranthi & UASB \\
3. & Arka Ahuti & IIHR & 15. & Vybhav & UASB \\
4. & Arka Ashish & IIHR & 16 & NS -2535 & Namdhari Seeds \\
5. & Arka Abha & IIHR & 17 & Mruthyunjaya -2 & Sasya Seeds \\
6. & Arka Megali & IIHR & 18 & US -618 & U.S. Agriseeds \\
7. & Arka Saurab & IIHR & 19 & J.K. Desi & J.K. Agrigenetics \\
8. & Arka Shresta & IIHR & 20 & J.K. Asha & J.K. Agrigenetics \\
9. & Arka Abijeet & IIHR & 21 & Ronco & Bejo Seeds \\
10. & Pusa Ruby & IARI & 22 & A -32/63 & Indosem Seeds \\
11. & Pusa Early Dwarf & IARI & 23 & $128 / M 131$ & Indosem Seeds \\
12. & PKM -1 & TNAU & 24 & M-03/868 & Indosem Seeds \\
\hline
\end{tabular}

\section{Standard phenol test:}

Two hundred $(50 \times 4)$ seeds were presoaked in distilled water for $24 \mathrm{~h}$ at 25 $\pm 1^{\circ} \mathrm{C}$. Then they were transferred on to two layers of Whatman No.1 filter paper saturated with one per cent phenol solution. The petri dishes were covered and incubated at $25 \pm 1^{\circ} \mathrm{C}$ and the colour reactions were noted after $24 \mathrm{~h}$. Based on the development of seed coat colour, the selected cultivars were classified into different categories as No change in colour, Light brown, Brown, Dark brown, Light grey, Grey and Dark grey

\section{Modified phenol test}

Modified phenol test was conducted similar to standard phenol test except that seeds were soaked either in 0.5 per cent $\mathrm{CuSO}_{4}$ or one per cent $\mathrm{FeSO}_{4}$ solution for $24 \mathrm{~h}$ instead of distilled water. Colour reaction was noted after $48 \mathrm{~h}$ of incubation and the cultivars were classified based on colouration of seed coat into different categories as No colour change, Light brown, Brown, Dark brown, Light grey, Grey and Dark grey.

\section{$\mathrm{NaOH}$ test}

Seeds were soaked in two per cent $\mathrm{NaOH}$ solution for one hour and thereafter change in colour of the solution was observed. Based on the intensity of the colour reaction, the genotypes were classified into two groups viz., no change in colour, yellow and light yellow. 


\section{KOH test}

Seeds were soaked in four per cent $\mathrm{KOH}$ solution for three hours and thereafter change in colour of the solution was observed. Based on the intensity of the colour reaction, the genotypes were classified into two groups viz., no change in colour and reddish brown.

\section{Seedling growth response to added chemicals}

Seedling growth response to $\mathrm{GA}_{3}$ application: The increase in shoot length, root length and primary leaf length due to exogenous application of $\mathrm{GA}_{3}$ was measured. The seeds $(100 \times 4)$ were soaked in $50 \mathrm{ppm} \mathrm{GA}$ solutions for $24 \mathrm{~h}$ and then germinated in rolled towels at $25 \pm 1^{\circ} \mathrm{C}$ as per ISTA (1996). Twenty five seedlings were selected randomly and growth response was measured at $14^{\text {th }}$ day of germination in terms of per cent increase in shoot length and root length over control. The mean of increased seedling length was determined and the cultivars were grouped into five categories (Agarwal and Pawar, 1990) based per cent increase over control viz., Very low response $(<25 \%)$, Low response type ( 25 to $50 \%$ ), Medium response type (50 to $75 \%$ ), High response type (75 to $100 \%)$ and Very high response type (>100\%) .

Seedling growth response to kinetin application: The increase in shoot length, root length and primary leaf length due to exogenous application of kinetin was measured. The seeds $(100 \times 4)$ were soaked in $50 \mathrm{ppm}$ kinetin solutions for 24 hours and then germinated in rolled towels at $25 \pm 1^{\circ} \mathrm{C}$ as per ISTA (1996). Twenty five seedlings were selected randomly and growth response was measured at $14^{\text {th }}$ day of germination in terms of per cent increase in shoot length and root length over control. The mean of increased seedling length was determined and the genotypes were grouped into five categories according to Agarwal and Pawar (1990) based per cent increase over control viz., Very low response $(<25 \%)$, Low response type $(25$ to $50 \%$ ), Medium response type (50 to $75 \%$ ), High response type (75 to $100 \%$ ) and Very high response type (>100\%).

Seedling growth response to 2,4-D application: The reduction in seedling growth due to exogenous application of 2,4-D was measured. The seeds $(100 \times 4)$ were soaked in $10 \mathrm{ppm}$ of 2,4-D solutions for $24 \mathrm{~h}$ and then tested for germination in rolled towels at $25 \pm 1{ }^{\circ} \mathrm{C}$ as per ISTA (1996). Growth response was measured on seventh day in terms of per cent decrease in shoot length over control. The reduction in mean seedling length was expressed and based on growth inhibition, the genotypes were classified into three categories (Agarwal and Pawar 1990) viz., Highly resistant type $(<30 \%)$, Medium resistant type (30 to 60\%) and Low resistant type ( $>60 \%)$.

The data was analyzed statistically by following Completely Randomized Design (CRD) and adopting "Fischer's Analysis of Variance Technique" critical difference values were calculated at 5 per cent probability level 
(where "F" test was significant). Dunnett's "t" test was then performed to compare control with all other treatments (Panse and Sukhatme, 1967).

\section{RESULTS AND DISCUSSION}

\section{Chemical tests}

Seeds constituents vary between the cultivars. The reaction of these constituents with chemicals resulted in different reaction. Various biochemical tests are being used to reveal chemical differences among the seeds or seedlings of different cultivars. They require virtually no technical expertise or training and can be completed in a relatively short time. The results of these test are usually distinct, easily interpreted and helps in distinguishing or grouping of cultivars. Phenol colour reaction depends on quality and quantity of oxidative enzymes present in seeds (Walla, 1965). Whereas, monophenol oxidase is extremely localized in seeds, even though it is present in all other plant parts (Takahashi and Hamza, 1983). Phenol colour reaction is an index of polyphenol oxidase activity, has been utilized to distinguish the crop varieties (Joshi and Banerjee, 1970, Abrol and Uperty, 1972, Chauhan and Nanda, 1984, Sparks et al., 1985).

An attempt to characterize 24 tomato cultivars was made based on the phenol colour reaction test. Cultivars Arka Vikas, Arka Ahuti, Arka Megali, Arka Saurab, Nandi, Sankranthi, Vybav, NS-2535, JK Desi, 128/M 131 did not respond to phenol reaction. Among reacted cultivars Arka Alok, Arka Shresta, Arka Ashish, Pusa Early Dwarf, US-618, JK Asha, A 32/63, M03/868, Mruthunjaya-2, Ronco showed light brown and Arka Abha, Arka Abijeet, Pusa Ruby showed brown colour. Only PKM-1 was distinct from other cultivars by its dark grey colour and could be used as marker to identify from rest of the cultivars (Fig 1).

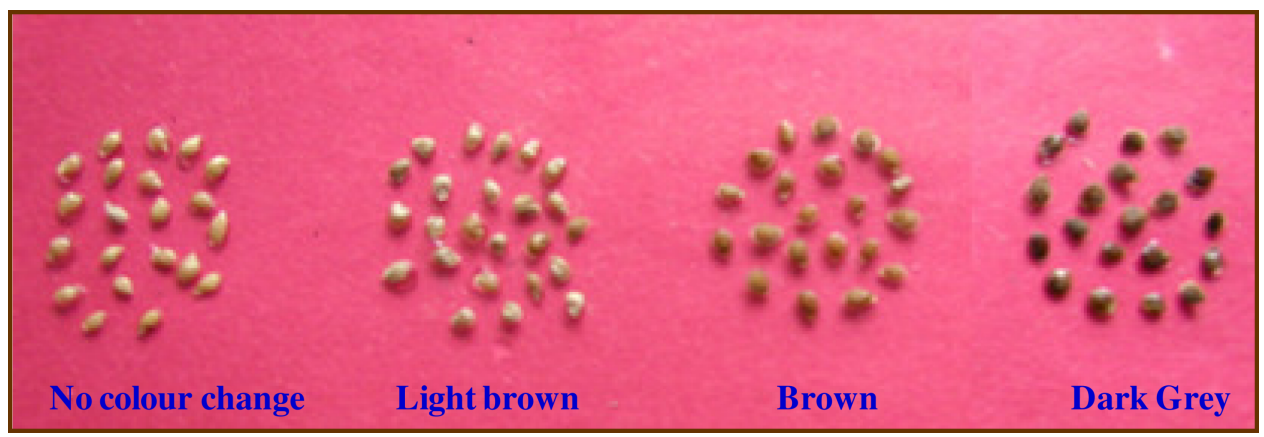

Fig1.ReactionofseedtoStandardPhenolTest

Colour reaction of phenol was enhanced by using $\mathrm{Cu}^{++} / \mathrm{Fe}^{++}$as a catalyst by using $\mathrm{CuSO}_{4}$ and $\mathrm{FeSO}_{4}$. Based on this the cultivars were classified into seven 
groups as no colour change, light brown, brown, dark brown, light grey, grey and dark grey. Arka Saurab was distinct by its no colour reaction with either $\mathrm{CuSO}_{4}$ or $\mathrm{FeSO}_{4}$, cultivar Arka Vikas by its dark grey with $\mathrm{Fe}^{++}$ions. Hence, based on colour reaction with phenol and modified phenol test genotypes can be classified into different groups and phenol test with $\mathrm{FeSO}_{4}$ found to be better in distinguishing the cultivars (Fig 2). The presence of metallic ions $\mathrm{Fe}^{++}$and $\mathrm{Cu}^{++}$ in modified phenol test enhances the phenol colour reaction since it is an enzymatic reaction and these ions acts as catalyst (Banerjee and Chandra, 1977), which was confirmed by Gupta and Agarwal (1988), Agarwal and Karki (1989). Further, phenol colour reaction of seeds seems to be due to the difference in the genetic background, presumably concerning the enzyme system (Takahashi and Hamza, 1983). The genotypes were grouped based on phenol colour reaction test in several crop palnts by Meshram and Ratiangdale (1988), Wang and Shen (1992), Vnanagmudi et al., (1988), Panwar and Ram (1988) in Wheat, Jaiswal and Agarwal (1995) and Nethra et al., (2007) in rice. In the present study, additional three more colour categories could be observed viz., light grey, grey and dark grey which was not reported by earlier studies on any crops. The present findings revealed that phenol and modified phenol test with $\mathrm{CuSO}_{4}$ and $\mathrm{FeSO}_{4}$ could be used as simple, quick and cheap method for identification of some studied cultivars and grouping of most of the cultivars.

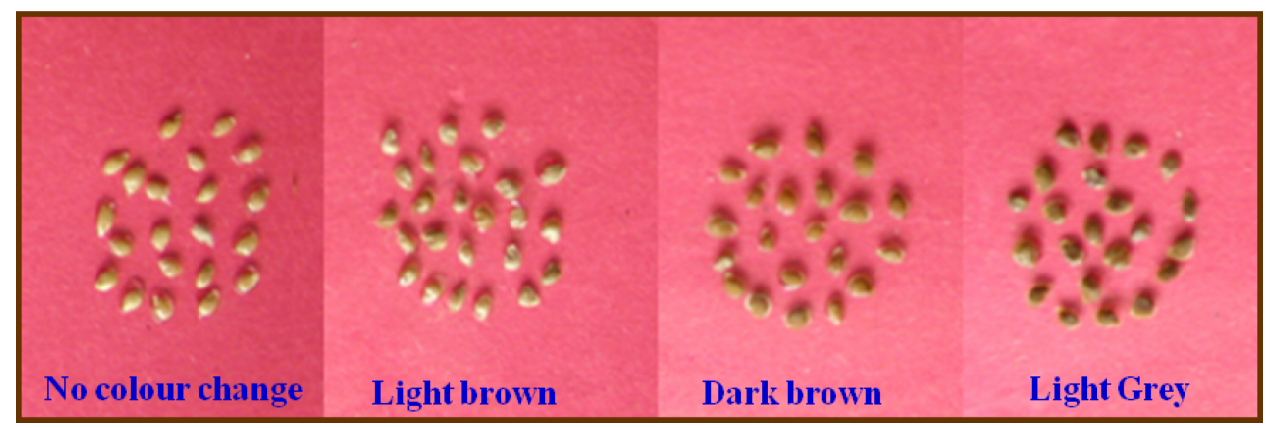

Fig 2. Reaction of seed to Modified Phenol Test with $\mathrm{CuSO}_{4}$

Based on the colour reaction to $\mathrm{NaOH}$ and $\mathrm{KOH}$ the cultivars were grouped into three and four categories respectively. Based on $\mathrm{NaOH}$ test cultivars were categorized into no colour change, light yellow and dark yellow. Seventeen cultivars did not respond to $\mathrm{NaOH}$ test by showing no colour change. However, cultivar A 32/63 was distinct from other cultivars by its dark yellow stain. Based on $\mathrm{KOH}$ test cultivars, were categorized into four categories viz., no colour change, light yellow, dark yellow and wine red. Nine cultivars did not respond to KOH test. Cultivar NS-2535 was distinct from rest of the cultivars by its wine red staining (Fig 3). The difference in colour change to either $\mathrm{NaOH} / \mathrm{KOH}$ was due to difference in seed constituents. One extra category dark yellow was found and was utilized for grouping of genotypes than earlier categories which werereported by many 
scientists (Vanangamudi et al., 1998, Nethra et al., 2007 in rice Mc Donald Jr., 1985, Punia et al., 2002 in wheat, Patil et al., 2006 in safflower, Papp et al., 1997 in Brassica spp.). However, in present study wine red category was not found in $\mathrm{NaOH}$ test but found in $\mathrm{KOH}$ test.

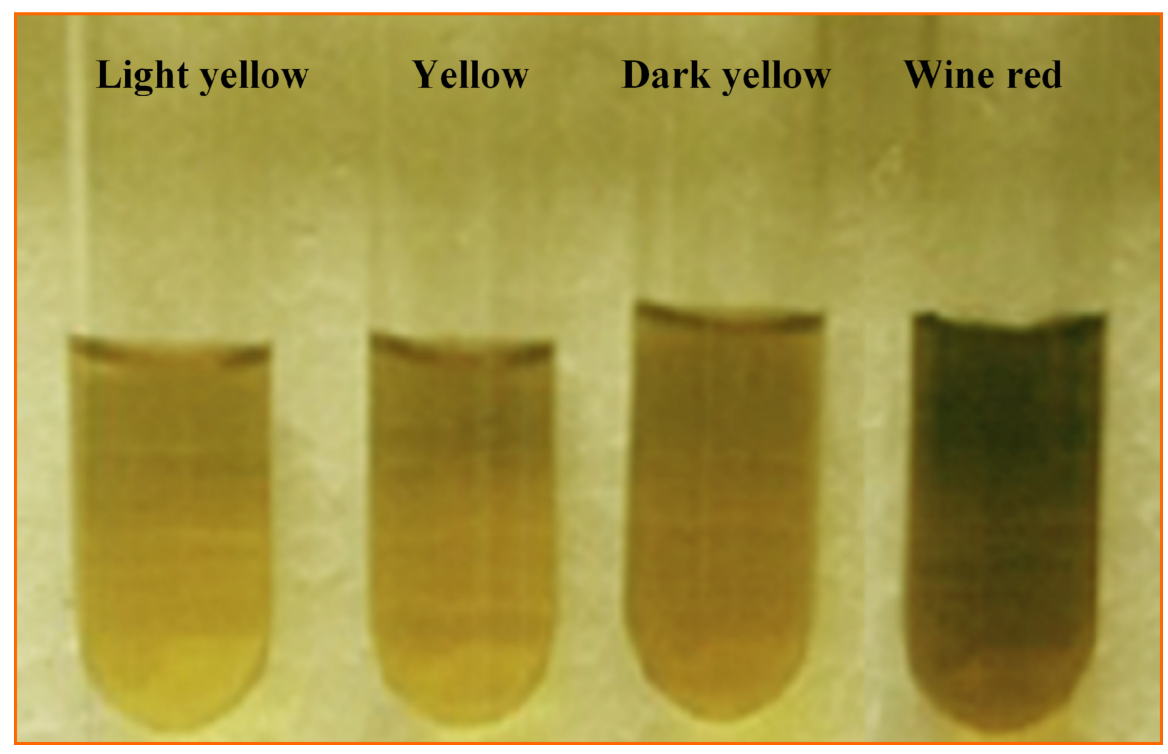

Fig 3. Reaction of seed to $\mathrm{KOH}$ test

\section{Seedling response to added chemicals}

The growth response of cultivars to nutrients or growth regulators is mainly governed by its genetic make up and expression of genes at specific condition. The effect of growth regulators on seedling growth behavior has been used in characterizing cultivars of several crops. (Nethra et al., 2007 in rice, Agarwal and Sharma, 1989, in bean. Patil et al., 2006 in safflower).

Based on response to $\mathrm{GA}_{3}$, cultivars were grouped into five categories viz., very low $(<25 \%)$, low $(25-50 \%)$, medium $(50-75 \%)$, high $(75-100 \%)$ and very high $(>100 \%)$. Only cultivar NS-2535 was distinct by its very high $(156.00 \%)$ response to $\mathrm{GA}_{3}$ followed by JK Desi (97.49\%). Very low response (11.61\%) was noticed in Arka Megali. All the cultivars were grouped based on response to $\mathrm{GA}_{3}$. Similar results were reported by Goyal and Baijal (1980) who opined that differences might be due to increased RNA activity or due to differences in cell division (Terao,1986)

Cultivar Arka Alok was distinct from rest of the cultivars by its very low response $(<25 \%)$ to $50 \mathrm{ppm}$ kinetin. Arka Ahuti, Arks Saurab and PKM-1 were also distinct by their medium response (50-75\%) to kinetin. Similarly, Mruthunjaya-2, JK Asha, Ronco, 128/M 131 by their high response (75- 
$100 \%)$. Rest of the cultivars were categorized either in to low $(25-50 \%)$ or very high $(>100 \%)$. Cultivar Pusa Ruby showed maximum response (136.60\%) followed by Arka Abijeet (108.33\%) (Table 2). The increase in growth might be due to amplified cell division during early phases of seed germination (Prasad and Roy, 1999 in pigeon pea, Nethra et al., 2006 in rice).

The highest reduction in growth due to exogenous application of 2,4-D was observed in Mruthunjayua-2 (157.55\%) followed by NS-2535 $(109.60 \%)$ and least in Pusa Ruby (30.92\%). Most of the cultivars were grouped under highly susceptible $(>60 \%)$ category except cultivars Arka Alok, Arka Vikas, Arka Ashish, Arka Abha, Arka Saurab, Pusa Ruby and M-03/868 which showed susceptible nature (Table.2). However, no cultivar was tolerant to 2,4-D. The differences in reduction in seedling growth among genotypes might be due to differential ethylene production upon application of 2,4-D (Sundaru et al., 1983) which governed signal transduction and expression of specific gene for external stimuli which is further controlled by genetic make up of genotype.

Table 2

Response of cultivars of tomato to different growth regulators.

\begin{tabular}{rlcccc}
\hline S1 No. & Genotypes & Control & $\begin{array}{c}\mathrm{GA}_{3} \\
{[50 \mathrm{ppm}]}\end{array}$ & $\begin{array}{c}\text { Kinetin } \\
{[50 \mathrm{ppm}]}\end{array}$ & $\begin{array}{c}2,4-\mathrm{D} \\
{[10 \mathrm{ppm}]}\end{array}$ \\
\hline 1. & Arka Alok & 13.89 & 12.52 & 11.79 & 51.07 \\
2. & Arka Vikas & 14.66 & 39.61 & 150.0 & 31.50 \\
3. & Arka Ahuti & 14.54 & 24.59 & 50.10 & 73.38 \\
4. & Arka Ashish & 14.67 & 39.11 & 30.55 & 41.11 \\
5. & Arka Abha & 15.89 & 24.12 & 38.46 & 48.91 \\
6. & Arka Megali & 14.56 & 11.61 & 43.11 & 62.91 \\
7. & A. Saurab & 14.89 & 24.79 & 56.11 & 52.12 \\
8. & Arka Shresta & 13.99 & 67.27 & 103.24 & 81.91 \\
9. & Arka Abijeet & 14.00 & 62.72 & 108.33 & 81.64 \\
10 & Pusa Ruby & 14.69 & 10.00 & 136.60 & 30.92 \\
11. & Pusa Early Dwarf & 14.89 & 13.66 & 38.46 & 60.96 \\
12. & PKM-1 & 14.87 & 42.22 & 51.23 & 71.12 \\
13. & Nandi & 14.68 & 43.90 & 42.55 & 76.18 \\
14. & Sankranthi & 14.84 & 28.18 & 43.41 & 74.85 \\
15. & Vybhav & 15.87 & 53.08 & 67.74 & 77.13 \\
16. & NS-2535 & 17.00 & 156.00 & 115.18 & 109.60 \\
\hline & & & &
\end{tabular}


Table 2

Continued

\begin{tabular}{|c|c|c|c|c|c|}
\hline Sl No. & Genotypes & Control & $\begin{array}{c}\mathrm{GA}_{3} \\
{[50 \mathrm{ppm}]}\end{array}$ & $\begin{array}{c}\text { Kinetin } \\
{[50 \mathrm{ppm}]}\end{array}$ & $\begin{array}{c}2,4-\mathrm{D} \\
{[10 \mathrm{ppm}]}\end{array}$ \\
\hline 17. & Mruthyanjaya-2 & 15.01 & 82.00 & 89.19 & 157.55 \\
\hline 18. & US -618 & 17.56 & 88.04 & 131.1 & 82.62 \\
\hline 19. & JK Desi & 16.89 & 97.49 & 1.0 .21 & 85.83 \\
\hline 20. & JK Asha & 17.06 & 89.19 & 99.11 & 87.45 \\
\hline 21. & Ronco & 15.11 & 86.36 & 89.28 & 74.96 \\
\hline 22 & A $32 / 63$ & 17.16 & 18.33 & 42.33 & 80.00 \\
\hline 23 & 128/M 131 & 15.00 & 30.78 & 82.05 & 39.72 \\
\hline \multirow[t]{2}{*}{24.} & M-03/868 & 13.05 & 43.12 & 45.43 & 57.33 \\
\hline & $\mathrm{SEm} \pm$ & 0.961 & 3.525 & 6.86 & 4.83 \\
\hline & $\mathrm{CD}(\mathrm{p}=0.05)$ & 2.693 & 9.88 & 19.36 & 13.61 \\
\hline
\end{tabular}

Through lone chemical test could not able to differentiate all the cultivars. However, distinguishable chemical characteristics were used to develop the keys for identification of each and every cultivar and all the cultivars were distinguished based on these identification keys. (Fig 4). Hence, these chemical tests are simple, quick, cost effective and virtually require no expertise and could be employed for varietal identification and characterization of tomato cultivars. 


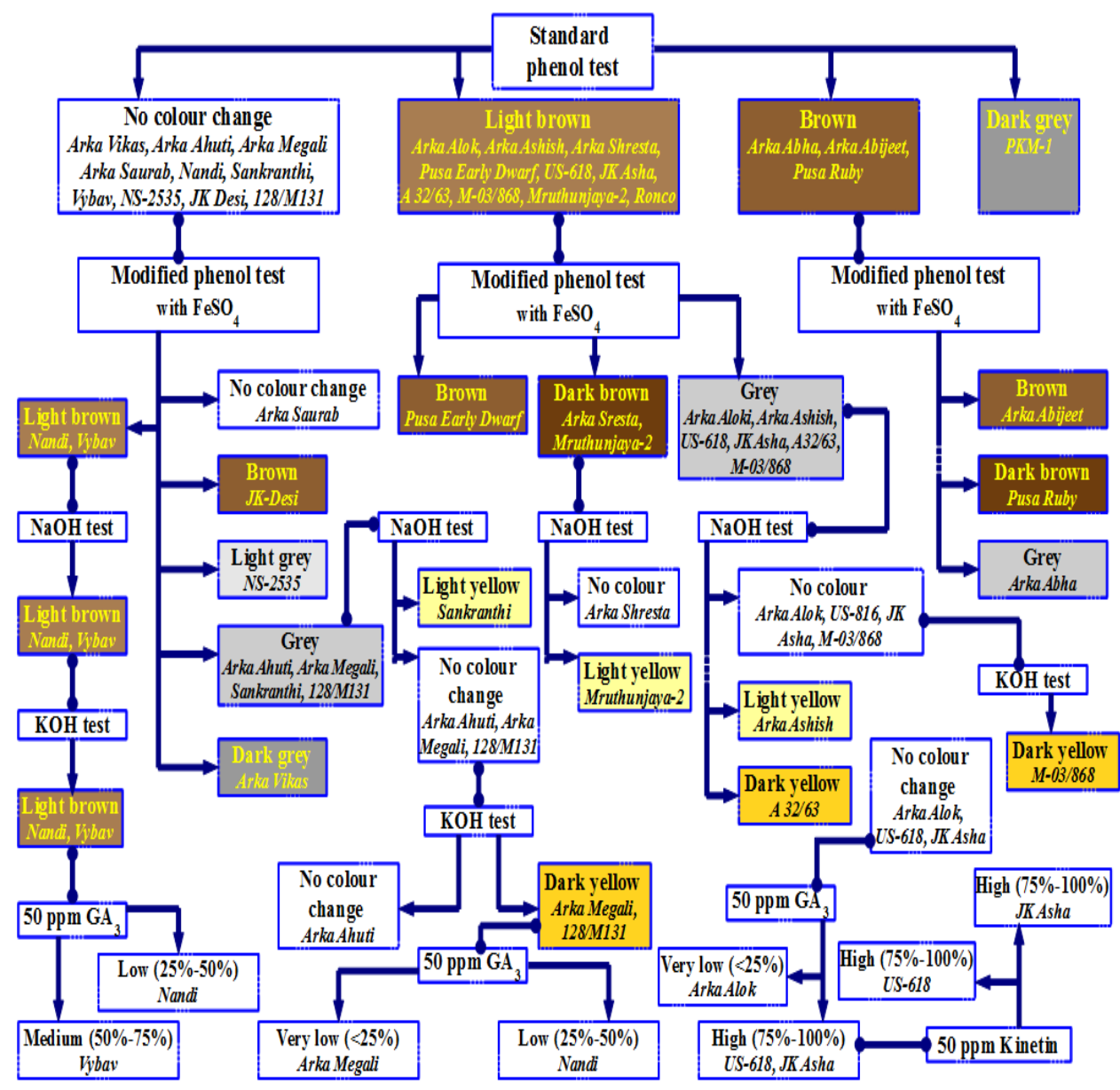

Fig 4. Identification Key based on chemical tests in tomato cultivars

\section{REFERENCES}

Abrol Y.P., Uprety D.C. 1972. Phenol colour reaction vis-à-vis discolouration of paddy. Bull. Grain. Technol., 10(4): 288-290

Agarwal R.L. Karki B.S. 1989. Identification of wheat varieties on the basis of laboratory evaluation. Univ. Agric. Technol. Pantnagar. Res. Bull., 116: 81.

Agarwal R.L. Pawar A. 1990. Identification of soybean varieties based on seed and seedling characteristics. Seed. Res., 18(1): 77-81.

Agarwal R.L., Sharma B.L. 1989. Identification of mung bean varieties on the basis of seedling growth response to $\mathrm{GA}_{3}$ and DDT treatment. Seed. Res., 17 (1): 84-87. 
Arus P. Tanksley S.D. Oroton T.J. Jones R.A. 1982. Electrophoresis variation as a tool for determining seed purity and for breeding hybrid varieties of Brassica oleraceae. Euphytica, 31: 417-428.

Banerjee S.K. Chandra S. 1977. Modified phenol test for the varietal identification of wheat seed. Seed Sci. \& Technol., 5(1) 53-60.

Chauhan J.S. Nanda J.S. 1983. Genetic variability for physico-chemical characters of rice grain in segregation O. sativa L. Oryza 20: 209-215.

Goyal A.K. Baijal B.D. 1980. Effect of GA and RNase activity and RNA contents at early seedling stage in certain rice (O. sativa L.) genotypes. Indian J. Agric. Res., 14(2): 111-114.

Gupta P.K. Agarwal R.L. 1988. Determination of varietal purity of paddy varieties by laboratory evaluation. Oryza 25: 310-314.

ISTA. 1993. Hand book of variety testing: Rapid Chemical identification techniques (Eds. Payme, R.C. USDA). Pub. ISTA, Zurich, Switzerland.

ISTA. 1996. International Rules for Seed Testing. (Suplliment) Seed Sci. \& Technol., 29: 1-135

Jaiswal J.P. Agarwal R.L. 1995. Varietal purity determination in rice modification of the phenol test. Seed Sci \& Technol 23: 33-42.

Joshi M.G. Banerjee S.K. 1970. Genetics of phenol colour reaction in emmer wheats. Proc. Int. Seed Test. Assoc., 35: 207.

Lucchese C. Dinelli G. Miggiano A. Lovato. 1999. Identification of pepper (Capsicum spp) cultivars by field and electrophoresis tests. Seed Sci. \& Technol., 27:37-47.

Mc Donald MB Jr. 1985. AOSA cultivar purity subcommittee report. AOSA Newsletter 59(1):40-57.

Meshram L.D. Rahangdale S.L. 1988. Studies on phenol test in rice. Ann. Pl. Physiol., 2(1): 107-109.

Nethra N. Rajendra Prasad S. Vishwanath K,. Dhanraj K.N. Ramegowda. 2007. Identification of rice hybrids and their parental lines based on seed, seedling characters, chemical tests and gel electrophoresis of Total soluble proteins. Seed Sci. \& Technol., 35:176-186.

Panse V.S. Sukhatme P.V. 1967. Statistical Methods for Agricultural workers. Indian Council of Agricultural Research Publication. New Delhi, India.

Panwar R.C, Ram C. 1998. Identification of wheat varieties by phenol and modified phenol tests. Proceedings of National Seminar of Seed Science and Technlogy. March 7-9, 1988, Hissar, India. P.134.

Papp E. Korosi F. Kemeny A. 1997. Identification of seeds of Brassica species on the basis of spectrophotometry of seed extracts. Seed Sci. \& Technol., 25: 577-580.

Patil. B.N.K, Sangeeta Macha, Motagi B.N. Vijayakumar A.G. Hanchinal R.R. 2006. Charaeterization of safflower varieties through chemical tests. Proceedings of XII National Seed Seminar on prosperity through quality seed, 24-26 ${ }^{\text {th }}$ February,2006, ANGRAU, Hyderabad, India p. 168

Prasad H. Roy D. 1999. Development of seed keys for varietal identification in pigeonpea (Cajanus cajan L.) using growth responses to added chemicals. Legume Res., 22(4): 249-253

Punia R.C. Chandgi R. Tomer R.P.S. Anita M. 2002. Cultivar identification of wheat by modified phenol tests. Seed Tech. News., 32 (1): 97.

Sparks G.A. May Gibbon D.B. Coles G.D. Slack C.R. 1985. Identification of rice genotypes. Nz. J. Exp. Agric., 13(4): 359-367.

Sundaru M. Baba I. Tanabe T, Tamai F., Matoda Y. 1983. Varietal differences of Indonesian rice plants in their susceptibility to 2, 4-D injury and inter-relationship with ethylene. Japanese J. Crop Sci., 52(3): 323 -330 .

Takahashi N. Hamaz A.H.A. 1983. Differentiation of ecotypes in Oryza sativa L. I: Re-examination for colour reaction with phenol. Japan J. Breed., 33(3): 243-250.

Tanksley S.D. Ganal S.D. Prince J.P. Broun P. Roder M.S. Young N.D. 1992. High density molecular maps of the tomato and potato genomes. Genetics, 132: 1141-1460.

Terao H. 1986. Studies on the mesocotyl elongation of seedlings in Japanese paddy rice cultivars, (O. sativa) L. Bull. Inst. Trop. Agric., 9: 77-87.

Vanangamudi K. Palanisamy V. Natesan P. 1998. Variety determination in rice- phenol and potassium hydroxide tests. Seed Sci. \& Technol., 16: 465-470.

Vishwanath K. Ananthararayanan T.V. Pallavi H.M. Ramegowda Rajendra Prasad S. Prasanna K.P.R. Shailaja H. 2010. Varietal Characterization of Tomato Cultivars Based on RAPD Markers. Res. J. Agril. Biol. Sci., 6(6): 713-715.

Walls F.W. 1965. Standardization of phenol method for testing of wheat for varital purity. Hand Book on Seed Testing, AOSA, Contribution No. 28.

Wang J. Shen Z. 1992. Study on the classification of American rice varieties. Crop Gen. Resour., 2: 4-6.

Wang X.F. Konoblauch R. Leist N. 2000. Varietial discrimination of tomato (Lycopersicon esculentum Mill.) by ultra thin - layer isoerlectric focusing of seed protein, Seed Sci \& Technol., 28:521-526. 